\title{
A cross sectional study of liver function tests in normal pregnancy during third trimester: a treasure from the past
}

\author{
Nirpaul Singh ${ }^{1}$, Shagufta Yousuf ${ }^{1}$, Showkat H. Tali*
}

\begin{abstract}
${ }^{1}$ Department of Obstetrics and Gynecology, Adesh Institute of Medical Sciences and Research, Bathinda, Punjab, India ${ }^{2}$ Assistant Professor, Department of Pediatrics and Chief Neonatologist, Adesh Institute of medical sciences Bathinda Punjab, India
\end{abstract}

Received: 11 January 2017

Accepted: 08 February 2017

\section{*Correspondence:}

Dr. Showkat H. Tali,

E-mail: drshowkatshifa@gmail.com

Copyright: (c) the author(s), publisher and licensee Medip Academy. This is an open-access article distributed under the terms of the Creative Commons Attribution Non-Commercial License, which permits unrestricted non-commercial use, distribution, and reproduction in any medium, provided the original work is properly cited.

\begin{abstract}
Background: During pregnancy, a lot of changes do occur and affect every organ system in the body. Objective of the study was to find out expected variations, if any, in liver function tests (LFT) in normal pregnancy during the third trimester.

Methods: A total of 75 women aged between 20 to 35 years were enrolled in the study of which 25 were nonpregnant women (control group) and 50 were pregnant women in their third trimester (study group).

Results: In the study group, there were no changes in SGPT, serum albumen and serum globulin values in any of the subjects. However out of 50 subjects, a rise in serum alkaline phosphatase could be demonstrated in as many as 44 $(88 \%)$ subjects. In $10(20 \%)$ subject Serum Bilirubin was high and in $6(12 \%)$ subjects each a rise in SGOT and fall in Serum Proteins could be demonstrated.

Conclusions: Except for a significant change in serum phosphatase levels, there is no significant variation in any of the liver function tests in third trimester of pregnancy.
\end{abstract}

Keywords: Liver function tests, Pregnancy, Third trimester

\section{INTRODUCTION}

In fact, this study was conducted some 37 years back in 1980 but unfortunately has remained unpublished so far. How hard he (the first author) has worked on this research project (which was his thesis project in postgraduation) was a grand feast for me (corresponding author) to listen during a chat with him, at Adesh University. He told me how he was himself collecting the samples from the subjects, centrifuging them and then determining the levels of enzymes and proteins. Publishing this study in a scientific journal may not have a great impact on current guidelines on liver function test reference values but will surely encourage the budding researchers to strive harder in this age of ease to get the best out of the better. This may also encourage other researchers to send their left-out material for publication and who knows that something quite beneficial for humanity may come to fore through the material what the researchers may actually be thinking is useless, worn-out and out dated.

During pregnancy a lot of changes do occur and affect every organ system in the body. ${ }^{1}$ To separate these expected changes from the variations that result from unexpected pathological processes a lot of research has been done in the past, is going on at present and is expected to continue in future as well. ${ }^{2-4}$ This study was designed to find out expected variations, if any, in liver function tests (LFT) in normal pregnancy during the third trimester. 


\section{METHODS}

This cross sectional observational study was conducted in the Department of Obstetrics and Gynecology, Government Medical College Amritsar, Punjab, India. Study was conducted from 5 June 1979 to 4 June 1980. Subjects were enrolled in the study after taking approval from hospital ethical committee and written informed consent from the patients.

\section{Inclusion criteria}

Study group

Pregnant women in the age group of 20 to 35 years with gestational age between 25-40 weeks according to last menstrual period.

\section{Control group}

Non-pregnant women in the age group of 20 to 35 years.

\section{Exclusion criteria}

History suggestive of renal disorders, diabetes, cardiovascular disorders, liver disease, collagen vascular disease, thyroid disorders or other endocrine disorders, acute or chronic infections or drug intake.

Subjects in the study group were selected from outpatient department, antenatal clinics and wards of Obstetrics and Gynecology Department of Govt. Medical College Amritsar, Punjab, India. Control group consisted of nonpregnant women who were doctors, staff nurses, ward attendants and attendants of the patients from the same hospital. From all the participants, $5 \mathrm{ml}$ blood was taken from anti-cubital veins, with a dry syringe sterilized by autoclaving. This blood was kept in dry test tubes for half an hour and then centrifuged at 3000 revolution per minute for 10 minutes. Clear serum thus obtained was removed from the top and analyzed for liver function tests. When blood could not be processed immediately, it was stored in a refrigerator and used later on but only within 12 hours of collection. For bilirubin estimation Mallory and Evelyn method 5 was used. For Alkaline Phosphatase estimation, modified method of Bodensky was utilized. ${ }^{6}$ For estimation of SGOT and SGPT, colorimetric method modified by Reitman and Frankel was used. ${ }^{7}$ For estimation of serum proteins copper sulphate specific gravity method was used. For differential protein estimation Biuret method was utilized. ${ }^{8}$

\section{RESULTS}

Baseline characters have been shown in Table 1. Table 2 depicts liver function values obtained in the study population. Number of patients having liver function test values within and outside the expected range have been shown in Table 3.

Table 1: Baseline characteristics of control and study group.

\begin{tabular}{|c|c|c|c|}
\hline & $\begin{array}{l}\text { Parity } \\
\text { /gravidity }\end{array}$ & $\begin{array}{l}\text { No. of } \\
\text { subjects }\end{array}$ & $\begin{array}{l}\text { Hypertension, diabetes, } \\
\text { renal disease, collagen } \\
\text { vascular disease, acute } \\
\text { or chronic infection, } \\
\text { medications }\end{array}$ \\
\hline \multirow{5}{*}{$\begin{array}{l}\text { Control } \\
\text { group } \\
(n=25)\end{array}$} & Nullipara & $\begin{array}{l}11 \\
(44 \%)\end{array}$ & $0(0 \%)$ \\
\hline & Para 1 & $3(12 \%)$ & $0(0 \%)$ \\
\hline & Para 2 & $3(12 \%)$ & $0(0 \%)$ \\
\hline & Para 3 & $4(16 \%)$ & $0(0 \%)$ \\
\hline & Para 4 & $4(16 \%)$ & $0(0 \%)$ \\
\hline \multirow{2}{*}{$\begin{array}{l}\text { Study } \\
\text { group } \\
(\mathrm{n}=50)\end{array}$} & Primigravida & $21(42 \%)$ & $0(0 \%)$ \\
\hline & Multigravida & $29(58 \%)$ & $0(0 \%)$ \\
\hline
\end{tabular}

Table 2: Serum liver function tests in non-pregnant and pregnant women.

\begin{tabular}{|c|c|c|c|c|}
\hline Year (1980) & & $\begin{array}{l}\text { Control group } \\
(\mathbf{n}=\mathbf{2 5})\end{array}$ & Study population ( $\mathrm{n}=\mathbf{5 0}$ ) & $\begin{array}{l}\text { ACG guidelines } \\
(2016)^{9}\end{array}$ \\
\hline \multirow{2}{*}{ Total bilirubin (mg/100ml) } & Range & $0.3-0.8$ & $0.1-1.7$ & \multirow{2}{*}{ No change } \\
\hline & Mean \pm SD & $0.56 \pm 0.03$ & $0.7 \pm 0.09$ & \\
\hline \multirow{2}{*}{$\begin{array}{l}\text { Serum glutamic oxaloacitic acid } \\
\text { transaminase }(\mathrm{U} / \mathrm{L})\end{array}$} & Range & $5-23$ & $3-73$ & \multirow{2}{*}{ No change } \\
\hline & Mean \pm SD & $9.8 \pm 4.7$ & $20 \pm 15.2$ & \\
\hline \multirow{2}{*}{$\begin{array}{l}\text { Serum glutamic pyruvic acid } \\
\text { Transaminase (U/L) }\end{array}$} & Range & $5-6$ & $5-36$ & \multirow{2}{*}{ No change } \\
\hline & Mean \pm SD & $11.5 \pm 4.7$ & $13 \pm 7$ & \\
\hline \multirow{2}{*}{ Alkaline phosphatase (U/L) } & Range & $37-70$ & $45-95$ & \multirow{2}{*}{ Increases } \\
\hline & Mean \pm SD & $45 \pm 13$ & $66 \pm 13$ & \\
\hline \multirow{2}{*}{ Total protein $(\mathrm{gm} / 100 \mathrm{ml})$} & Range & $5.4-8.0$ & $5.2-7.5$ & \\
\hline & Mean \pm SD & $6.9 \pm 1.2$ & $6.5 \pm 0.6$ & \\
\hline \multirow{2}{*}{ Albumin (gm/100ml) } & Range & $3.6-5.5$ & $3.2-4.7$ & \multirow{2}{*}{ Decreases } \\
\hline & Mean \pm SD & $4.3 \pm 0.6$ & $4 \pm 0.5$ & \\
\hline \multirow{2}{*}{ Globulin (grams/100ml) } & Range & $1.5-3.6$ & $1.4-2.9$ & \multirow{2}{*}{ No change } \\
\hline & Mean \pm SD & $2.3 \pm 1.6$ & $2.4 \pm 0.013$ & \\
\hline
\end{tabular}


Table 3: Number of patients having LFT parameters within expected range.

\begin{tabular}{|c|c|c|c|c|}
\hline Year 1980 & Result & $\begin{array}{l}\text { Control group } \\
(\mathbf{n}=25)\end{array}$ & $\begin{array}{l}\text { Study group } \\
(\mathrm{n}=50)\end{array}$ & $\begin{array}{l}\text { ACG Guidelines } \\
(2016)^{9}\end{array}$ \\
\hline \multirow{2}{*}{ Total bilirubin (mg/100ml) } & Normal & 25 & 40 & \multirow{2}{*}{ No change } \\
\hline & Raised & 0 & 10 & \\
\hline \multirow{2}{*}{$\begin{array}{l}\text { Serum glutamic oxaloacitic acid transaminase } \\
\text { (U/L) }\end{array}$} & Normal & 25 & 44 & \multirow{2}{*}{ No change } \\
\hline & Raised & 0 & 6 & \\
\hline \multirow{2}{*}{ Serum glutamic pyruvic acid transaminase (U/L) } & Normal & 25 & 50 & \multirow{2}{*}{ No change } \\
\hline & Raised & 0 & 0 & \\
\hline \multirow{2}{*}{ Alkaline phosphatase(U/L) } & Normal & 18 & 3 & \multirow{2}{*}{ Increases } \\
\hline & Raised & 7 & 47 & \\
\hline \multirow{2}{*}{ Total proteins (grams/100ml) } & Normal & 25 & 44 & \\
\hline & Low (< 6 grams $)$ & 0 & 6 & \\
\hline \multirow{2}{*}{ Albumin (grams/100ml) } & Normal & 24 & 50 & \multirow{2}{*}{ Decreases } \\
\hline & Low & 1 & 0 & \\
\hline \multirow{2}{*}{ Globulin (grams/100ml) } & Normal & 25 & 50 & \multirow{2}{*}{ No change } \\
\hline & Raised /Low & 0 & 0 & \\
\hline
\end{tabular}

$\mathrm{ACG}=$ American college of Gastroenterology.

\section{DISCUSSION}

In present study, a total of 75 women were enrolled of which 25 were non-pregnant women who acted as controls and 50 pregnant women who were in their third trimester, acted as study population (Table 1). In the study group, there were no changes in SGPT, Serum Albumen and serum globulin values in any of the subjects. However out of 50 subjects, a rise in serum alkaline phosphatase could be demonstrated in as many as $44(88 \%)$ subjects. In $10(20 \%)$ subject serum bilirubin was high and in $6(12 \%)$ subjects each a rise in SGOT and fall in serum proteins could be demonstrated (Table $3)$.

In present study the majority of subjects (88\%) demonstrated a rise in serum alkaline phosphatase (mean \pm SD; study group 66 \pm 13 ; control group 45 \pm 13 ). McMaster et al and Curzen and Moris also demonstrated significant rise in alkaline phosphatase in third trimester $\left(123 \pm 38\right.$ and $289 \pm 128$ respectively). ${ }^{10,11}$ Maryam Al Salman obtained significantly high levels of serum ALP in his study population in the third trimester $(\mathrm{P}<0.05) .{ }^{12}$ ACG 2016 guidelines support the same. ${ }^{9}$

Serum bilirubin levels were normal in majority of the study population and were raised in as many of $20 \%$ of study population (mean $\pm \mathrm{SD} ; 0.1-0.7 \pm 0.09)$. Long et al demonstrated a rise in serum bilirubin levels where as Wetstone et al failed to demonstrate any rise in serum bilirubin. ${ }^{13,14}$ Gohel MG et al observed that serum total and direct bilirubin concentrations were significantly lower in second and third trimester. ${ }^{15}$ However ACG 2016 guideline support that there is no significant rise in serum belirubin levels in pregnancy. ${ }^{9}$

SGOT levels were normal in as many as $88 \%$ of our study population (mean \pm SD; 20 \pm 15.2 ). Friedman et al and Santhagopalan et al obtained similar results (mean \pm SD; 23.8 $\pm 5.4,18 \pm 12 ; 9.46 \pm 3.78$ ) respectively. ${ }^{16,17}$ In present study SGPT levels were also within normal

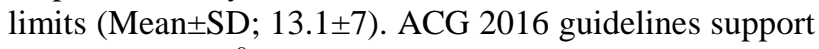
the same notion. ${ }^{9}$

Serum protein was within normal limits in majority of study the population ( $88 \%$ of subjects; Mean \pm SD; $6.5 \pm 0.6)$. There was also no change in serum albumin and serum globulin levels (mean $\pm \mathrm{SD} ; 4 \pm 0.5$ and $2.4 \pm 0.01$ respectively). McDonald and Good et al and Gohil MG obtained the similar results. ${ }^{15,18}$

\section{CONCLUSION}

Apart from a significant rise in serum alkaline phosphatase levels, there is hardly any clinically meaningful change in serum bilirubin, SGOT, SGPT, total serum proteins, serum albumen and serum globulin levels in third trimester of pregnancy.

\section{Funding: No funding sources}

Conflict of interest: None declared

Ethical approval: The study was approved by the Institutional Ethics Committee

\section{REFERENCES}

1. Locktich G. Clinical biochemistry of pregnancy. Crit Rev Clin Lab Sci. 1997;34:6.

2. Soma-Pillay P, Catherine NP, Tolppane H, Mebazaa A, Tolppanen H, Mebazaa A. Physiological changes in pregnancy. Cardiovascular J Africa. 2016;27(2)89-94.

3. Rodger M, Sheppard D, Gandara E, Tinmouth A. Haematological problems in obstetrics. Best Prac Res Clin Obstet Gynaecol. 2015;29(5):671-84. 
4. Tkachenko O, Shchekochikhin D, Schrier RW. Hormones and hemodynamics in pregnancy. Int $\mathrm{J}$ Endocrinol Metab. 2014;12(2):e14098.

5. Mallory HT, Evelyn KA. The determination of bilirubin with the photoelectric colorimeter. J Biol Chem. 1937;119:481.

6. Bodansky O. Acid Phosphatase. Adv Clin Chem. 1972;15:43-147.

7. Reitman S, Frankle S. A colorimetric method for the determination of serum glutamic oxalacetic and glutamic pyruvic transaminases. Am J Clin Path. 1957;28(1):56-63.

8. Ferdinand Rose. "Über die Verbindungen des Eiweiss mit Metalloxyden (On the compounds of albumin with metal oxides). Poggendorfs Annalen der Physik und Chemie. 1833;104:132-42.

9. Tran TT, Ahan J, Reau NS. ACG Clinical Guideline: liver disease and pregnancy. Am J Gastroenterol Adv. online publication. 2016;111:176-94.

10. McMaster Y, Tennant R, Club JS, Neale FC, Posen $\mathrm{S}$. The mechanism of the elevation of serum alkaline phosphatase in pregnancy. BJOG. 1964;71(5)735-9.

11. Curzen P, Morris I. Serum alkaline phosphatase in the hypertensive disorders of pregnancy. BJOG. 1965;7(3):397-401.

12. Salman MI. Changes in liver functions tests during pregnancy. J Al-Anbar Univ Pure Sci. 2009;3(1):209-12.

13. Long JS, Boysen H, Priest FO. Infectious hepatitis and pregnancy. Am J Obstet Gynecol. $1955 ; 70(2): 282-8$.
14. Wetstone HJ, Lamotta RV, Middlebrook L, Tennant R, White BV. Studies of cholinesterase activity. IV. Liver function in pregnancy: values of certain standard liver function tests in normal pregnancy. M J Obstet Gynecol. 1958;76(3):480-90.

15. Gohel MG, Joshi AG, Anand JS, Jemil SJS, Kamariya CP. Evaluation of changes in liver function test in first, second and third trimester of normal pregnancy. Int $\mathbf{J}$ Reprod Contracept Obstet Gynecol. 2013;2(4):616-20.

16. Friedman MM, Lapan B. Variations of enzyme activities during normal pregnancy. Am J Obstet Gynecol. 1961;82:132-7.

17. Santhanagopalan I, Mukherji SN. Leucine aminopeptidase activity in maternal and neonatal blood. Indian J Pathol Bacteriol. 1965;17:18-20.

18. Macdonald UN, Good W. Changes in plasma total protein, albumin, urea and amino nitrogen concentrations in pregnancy and the puerperium. $\mathrm{J}$ Obstet Gvnaecol. 1971;78:912-7.

Cite this article as: Singh N, Yousuf S, Tali SH. A cross sectional study of liver function tests in normal pregnancy during third trimester: a treasure from the past. Int J Reprod Contracept Obstet Gynecol 2017;6: $1105-8$ 